\title{
PROBLEMATYKA \\ TRANSLACYJNO-DYDAKTYCZNA W MISYJNYM SEMINARIUM DUCHOWNYM NA PRZYKŁADZIE WYBRANYCH BIBLIZMÓW
}

\begin{abstract}
Zarys treści: Artykuł dotyczy badań nad frazeologią języka specjalistycznego, jakim posługuja się misjonarze oblaci. Badania rozpoczyna usystematyzowanie dostępnej wiedzy na temat biblizmów i zaproponowanie szczegółowej typologii biblizmów, po czym omówiony jest proces translacji biblizmów. Frazeodydaktyka jest ogniwem łączącym teorię nauki o związkach wyrazowych z procesem dydaktycznym. Po przeanalizowaniu wyników testu diagnostycznego wśród studentów i ojców oblatów w świetle teorii translacji następuje przygotowanie konkretnych technik nauczania biblizmów, dostosowanych do specyficznych potrzeb użytkowników badanego języka specjalistycznego.
\end{abstract}

Słowa kluczowe: tłumaczenie, język specjalistyczny, frazeologia, biblizm, frazeodydaktyka, język misjonarzy

Doniższy artykuł dotyczy badań nad frazeologią języka specjalistycznego, którym posługują się misjonarze oblaci. Misjonarze, jak i scholastycy stają przed problemem tłumaczenia terminów religijnych, a w tym także frazeologizmów określanych jako biblizmy.

Naszą analizę rozpocznie usystematyzowanie dostępnej wiedzy na temat biblizmów i dokonanie ich szczegółowej typologii, po czym omówimy proces translacji biblizmów. Frazeodydaktyka będzie ogniwem łączącym teorię nauki o 
związkach wyrazowych z procesem dydaktycznym. Po przeanalizowaniu wyników testu diagnostycznego wśród studentów i ojców oblatów w świetle teorii translacji nastąpi omówienie konkretnych technik nauczania biblizmów, dostosowanych do specyficznych potrzeb użytkowników badanego języka specjalistycznego.

Według J. Godynia (1995: 7) biblizmy to „wyrazy oraz utrwalone, stałe związki wyrazowe, które pochodzą z języka polskich przekładów Biblii lub powstały pod wpływem treści Biblii". Podobne definicje znajdziemy w wielu innych źródłach (por. Müldner-Nieckowski, Müldner-Nieckowski 2004: 16).

Zaproponowana poniżej typologia bazuje na korpusie wyselekcjonowanych biblizmów wygenerowanych ze słowników frazeologicznych ogólnych oraz ze słowników biblizmów, jak i słowników terminów i zwrotów religijnych (Czekierda 2004; S. Bąba, Liberek 2002; Godyń 1995; Kłosińska, Sobol, Stankiewicz 2005; Müldner-Nieckowski 2004). Jakkolwiek P. Müldner-Nieckowski i Ł. Müldner-Nieckowski twierdzą, iż Biblia stanowi raczej marginalne źródło frazeologizmów, choć ich rola jest nieco większa w języku książkowym (2004: 16), to w kontekście języka religijnego ich znaczenie zwiększa się wraz z frekwencyjnością zarówno w mówionym, jak i pisanym języku religijnym.

Poniższy schemat prezentuje wyczerpującą klasyfikację biblizmów, proponowaną przez autorów, opartą na ich złożoności strukturalno-syntaktycznej. Najogólniej biblizmy zostały podzielone na pojedyncze leksemy i frazeologizmy, czyli konstrukcje językowe złożone z co najmniej dwóch komponentów. W obrębie pojedynczych leksemów mieszczą się biblizmy onomastyczne, które są pochodnymi nazw własnych, oraz leksemy idiomatyczne. Pierwsze źródło biblizmów onomastycznych to imiona bądź nazwy funkcji przypisane ludziom, np. Judasz, Pharisee, drugie źródło to nazwy geograficzne, np. Jordan, Golgota. Leksemy idiomatyczne to także pojedyncze wyrazy o metaforycznym znaczeniu, lecz o innym źródłosłowie, np. mammon (z aramejskiego 'bogactwo'). Drugą grupę, czyli frazeologizmy, podzielono na trzy kategorie. Pierwsza, najbardziej rozbudowana, to biblizmy funkcjonujące jako składowa część zdania, następnie wyodrębniono związki idiomatyczne (np. kopać pod kimś dotki) oraz frazy, które mogą funkcjonować jako kompletne zdania, np. Kto wiatr sieje, burze zbiera. Kolokacje, kinegramy, ilustrujące ruch w swym semantycznym obrazie (np. palcem nie kiwnać/ruszyć) i związki frazeologiczne funkcjonują jako składowe części zdania. Kolokacje dzielą się dalej na porównania, które z kolei mogą opierać się na czasownikach, np. chwiać się jak trzcina, albo też na przymiotnikach lub przysłówkach, np. as meek as a lamb; frazeologizmy bliźniacze, także oparte na częściach mowy, np. odpłacaj dobrem za zło (czasownikowe), alfa i omega (rzeczownikowe), chodzić od Anna- 
sza do Kajfasza, Sodoma i Gomora (onomastyczne); oraz wyrażenia czasownikowo-rzeczownikowe, np. umywać ręce. Jako składnik zdania, poza kolokacjami i kinegramami, występują też biblizmy somatyczne, np. the hand of God, wykorzystujące części ciała; następnie wyróżniono frazeologizmy, które zostały podzielone również na części mowy, oraz na onomastyczne, oto egzemplifikacja: a wolf in sheep's clothing, rwać wtosy z glowy, fatszywy jak Judasz, doubting Thomas, traba jerychońska. Terminy natomiast stanowią osobną kategorię w formie pojedynczego leksemu lub frazeologizmu. Według J. Podrackiego (1998: 285f) termin rozumiemy jako „wyraz lub związek frazeologiczny o zasięgu ograniczonym społecznie, tj. używany przez specjalistów określonej dziedziny nauki lub techniki w sytuacjach oficjalnych". Ich cechami charakterystycznymi są: planowość, ścisłość, jednoznaczność, neutralność, brak ekspresywności.

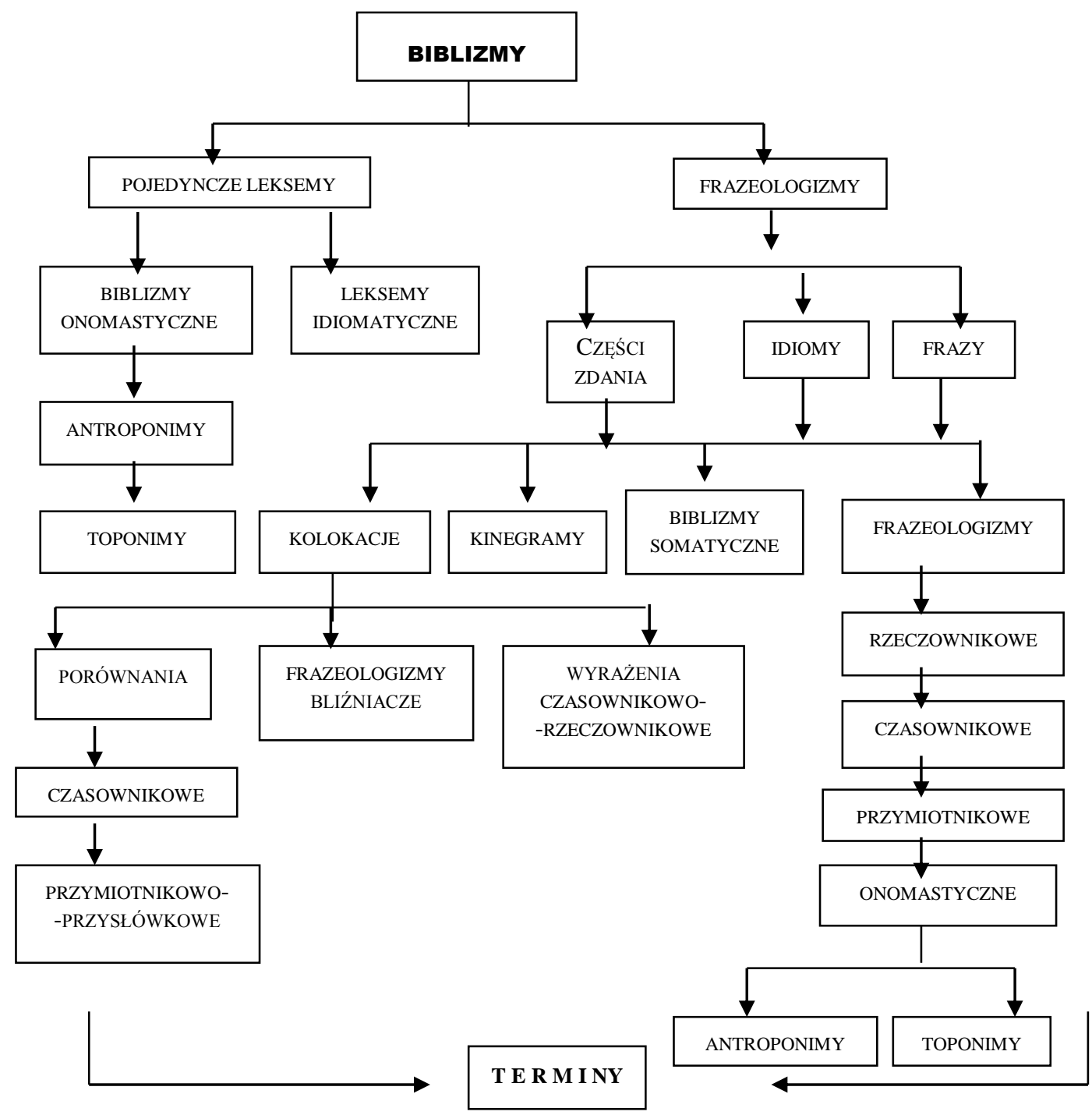


Zauważamy również, iż terminy przejmowane są czasem ze słownictwem języka potocznego za pośrednictwem asocjacji (por. Polański 1999: 602). H. Burger (1998: 46) twierdzi, iż grupa frazeologizmów terminologicznych funkcjonuje jak każdy inny termin. Są one dokładnie ustalone według określonej normy $\mathrm{i}$ to ustalenie obowiązuje prymarnie w obrębie fachowego subsytemu języka. Ich stabilność jest różna w zależności od kontekstu. Terminy zaliczane do pogranicza frazeologizmów (por. Müldner-Nieckowski, Müldner Nieckowski 2004: 16) są zatem pozbawione zabarwienia metaforycznego i mają jednoznacznie określone znaczenie, jak na kartach tłumaczeń Biblii, np. przybity do drzewa krzyża, obmycie nóg. Większość wyrażeń pochodzenia biblijnego jest nacechowana przenośnie i jednocześnie funkcjonuje w znaczeniu dosłownym jako terminy, np. cierniowa/ciernista korona jako biblizm oznacza 'mękę/udrękę', natomiast jako homonim dosłowny oznacza 'koło uplecione z cierni i włożone na głowę Chrystusa w czasie sądu nad Nim'. Należy zaznaczyć też istnienie biblizmów mających tylko i wyłącznie znaczenie idiomatyczne, odrywające się całkowicie od terminologii religijnej, np. mieć olej w głowie, gładkie słówka. W zasobach biblizmów występuje również zjawisko homonimii frazeologicznej, gdzie mamy do czynienia $\mathrm{z}$ więcej niż jednym znaczeniem przenośnym, np. anioł stróż oznacza 1)'opiekun, obrońca' oraz 2) 'policjant, agent śledczy', ponadto biblizm ten oznacza: 'anioł opiekujący się duszą danej osoby'.

Jak wynika z badań mitologizmów i biblizmów niemieckich w konfrontacji z polskimi odpowiednikami wykazują one najczęściej ekwiwalencję totalną lub częściową (Laskowski 2003: 9). Można zatem zakładać, iż komparacja angielskich i polskich biblizmów wykaże podobne rezultaty, zgodnie z supozycją, iż języki niemiecki, angielski i polski, należące do jednej rodziny językowej, mają także zbieżne procesy motywacji kognitywnej frazeologizmów. Badany korpus oparty jest na wyborze ze słowników biblizmów (por. Godyń 1995), słowników idiomów, przysłów, powiedzeń, a także ze słowników ogólnych. Analiza ekwiwalencji biblizmów badanych języków, jakkolwiek niewyczerpująca, bo ograniczona do około 250 przykładów, potwierdza wyniki wspomnianych badań przekładalności na języku niemieckim. Ekwiwalencja pełna, gdzie płaszczyzny: strukturalna, semantyczna i pragmatyczna pokrywają się, występuje $\mathrm{w}$ blisko $40 \%$, przykładowo: wiara góry przenosi $=$ faith moves mountains . Ekwiwalencja częściowa, gdzie nie ma pełnej zgodności na jednej z płaszczyzn, stanowi ponad 50\%, np. a wolf in sheep's clothing = wilk wowczej skó-

rze. Natomiast nieprzekładalność (ekwiwalencja zerowa), bez punktów stycznych na żadnej z płaszczyzn ekwiwalencji, to niewielka część korpusu bada- 
nych biblizmów, poniżej 10\%, np. chodzić od Annasza do Kajfasza = to go from pillar to post. Jeśli chodzi o przekład biblizmów istnieje kilka możliwych kombinacji (por. tabela poniżej). Jeśli językiem wyjściowym jest język polski, a nadawca prymarny posługuję się polskim biblizmem, to odbiorca terminalny języka docelowego (angielskiego) może otrzymać w komunikacie także biblizm lub frazeologizm (ale o innej etymologii), albo też parafrazę użytego biblizmu. Podobny mechanizm wystąpi w przypadku, gdy językiem oryginału będzie język angielski. Poniższa tabela ilustruje możliwe kombinacje thumaczenia wraz $\mathrm{z}$ egzemplifikacją. Problemy w thumaczeniu biblizmów mogą wynikać z wielorakich przyczyn. Jedną z nich stanowi powyżej przedstawiona kombinacja biblizm-parafraza. Homonimia biblizmów, często wzbogacona jeszcze o znaczenia dosłowne (terminy), będzie następnym utrudnieniem procesu translacji.

\begin{tabular}{|c|c|}
\hline \multicolumn{2}{|c|}{ KOMBINACJE TŁUMACZENIA BIBLIZMÓW } \\
\hline JĘZYK WYJŚCIOWY (POLSKI) & JĘZYK DOCELOWY (ANGIELSKI) \\
\hline $\begin{array}{l}\text { Biblizm (związek frazeologiczny) } \\
\text { oko za oko, zab za zab }\end{array}$ & $\begin{array}{l}\text { biblizm (związek frazeologiczny) } \\
\text { an eye for an eye, a tooth for a tooth }\end{array}$ \\
\hline $\begin{array}{l}\text { Biblizm (związek frazeologiczny) } \\
\text { chodzić od Annasza do Kajfasza }\end{array}$ & $\begin{array}{l}\text { inny związek frazeologiczny } \\
\text { to go from pillar to post }\end{array}$ \\
\hline $\begin{array}{l}\text { Biblizm (związek frazeologiczny) } \\
\text { mieć olej w głowie }\end{array}$ & $\begin{array}{l}\text { parafraza } \\
\text { to be reasonable/sensible }\end{array}$ \\
\hline JĘZYK WYJŚCIOWY (ANGIELSKI) & JĘZYK DOCELOWY (POLSKI) \\
\hline $\begin{array}{l}\text { Biblizm (związek frazeologiczny) } \\
\text { forbidden fruit }\end{array}$ & $\begin{array}{l}\text { biblizm (związek frazeologiczny) } \\
\text { zakazany owoc }\end{array}$ \\
\hline $\begin{array}{l}\text { Biblizm (związek frazeologiczny) } \\
\text { to be as old as the hills }\end{array}$ & $\begin{array}{l}\text { inny związek frazeologiczny } \\
\text { być starym jak świat }\end{array}$ \\
\hline $\begin{array}{l}\text { Biblizm (związek frazeologiczny) } \\
\text { born again }\end{array}$ & $\begin{array}{l}\text { parafraza } \\
\text { nawiedzony/nowo nawrócony }\end{array}$ \\
\hline
\end{tabular}

Niektóre ekwiwalenty polskich biblizmów są ograniczone do danej odmiany języka docelowego, zwykle o potocznym kwalifikatorze stylistycznym, np. brytyjskiej (np. być przedpotopowym = to be out of the ark (GB)), co także stanowi trudność w thumaczeniu. Także stopień łączliwości, gdzie wariantywność form, zwykle w obrębie wyrazów bliskoznacznych, jest także przyczyną utrudnień w thumaczeniu, gdyż często tłumacz przywiązany jest do tylko jednej formy, dla przykładu biblizm: cichy jak baranek ma inne warianty, np. potulny jak baranek, pokorny jak baranek, cichy jak owca etc. Inny problem to ortograficzne warianty pisowni wielką bądź też małą literą w przypadku antropologicznych biblizmów onomastycznych. W najnowszych słownikach frazeolo- 
gicznych i słownikach języka polskiego istnieje niezgodność co do pisowni form takich jak: S/sodoma i G/gomora, J/judasz itp. w ich sensie metaforycznym (por. bibliografia).

Test diagnostyczny, sprawdzający znajomość biblizmów wśród studentów seminarium o umiejętnościach powyżej poziomu średnio zaawansowanego, składał się z trzech zadań. W pierwszym zadaniu test wielokrotnego wyboru sprawdzał pasywne umiejętności z zakresu frazeologii biblijnej. Kolejne dwa zadania to thumaczenia, najpierw z języka angielskiego na język polski i następnie odwrotnie. Bazą wyjściową są biblizmy zaczerpnięte $z$ języka polskiego, wybrane z korpusu typologicznego lub ich angielskie ekwiwalenty, w przypad$\mathrm{ku}$ thumaczenia $\mathrm{z}$ angielskiego na polski. Po przeanalizowaniu wyników testu diagnostycznego wyłania się ewidentna korelacja pomiędzy stopniem ekwiwalencji badanych frazeologizmów a poziomem ich poprawnego thumaczenia. Wykres poniżej ilustruje wyniki thumaczenia trzech wyselekcjonowanych biblizmów o zróżnicowanym stopniu ekwiwalencji.

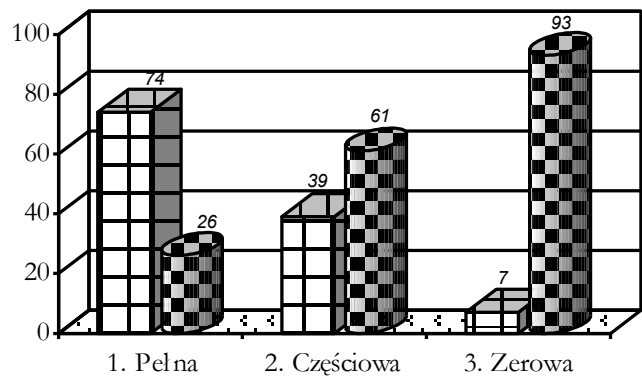

D Odpowiedzi poprawne

- Odpowiedzi niepoprawne

Wyniki wykazują, iż zadanie diagnostyczne wymagające aktywnego posługiwania się biblizmami w języku angielskim okazało się bardzo trudne, bo odpowiedzi poprawne stanowiły poniżej $30 \%$. Dla porównania najmniej wymagające było oczywiście zadanie sprawdzające receptywną wiedzę (test wyboru), gdzie poprawność wyniosła ponad $65 \%$.

Frazeodydaktyka stanowi stosunkowo nową dziedziną leksykologii, szczególnie w publikacjach polskich. Ze względów praktycznych spróbujmy przybliżyć przykładową koncepcję P. Kühna, która składa się z trzech etapów nauczania związków frazeologicznych: odkryć, rozkodować i zastosować. Pierwszy krok polega na rozpoznaniu związków frazeologicznych, czyli rozróżnieniu ich cech kontekstowych i tekstowych oraz strukturalnych. Drugi etap powinien służyć próbie odczytania znaczenia za pomocą słownika, własnej intuicji lub przy pomocy nauczyciela. $\mathrm{W}$ ostatniej fazie frazeodydaktycznego procesu, $\mathrm{w}$ którym oczekuje się poprawnego zastosowania frazeologizmów przez uczących się języka obcego, chodzi o konkretne sytuacje zastosowania związków frazeo- 
logicznych. Właśnie tu chodzi szczególnie o kontekstualność wszystkich ćwiczeń (Kühn 1994: 425). Ettinger (1998: 207) zastanawia się, czy możliwe jest zrealizowanie założeń tej części. Należy przyznać, że trójstopniowa koncepcja frazeodydaktyczna Kühna: odkryć - odkodować - zastosować - jest pracochłonnym i czasochłonnym procesem dydaktycznym, ale tylko w ten sposób można wprowadzić uczniów w skomplikowany świat frazeologii z jego wymogami semantyczno-pragmatycznymi. Następnie należałoby uwzględnić kontekstowe zastosowanie frazeologizmów szczególnie reprezentujących ekwiwalencję całkowitą i częściową. Istotne znaczenie ma tu przyporządkowanie treści do rodzajów tekstu z ich stylistycznym zabarwieniem (Hessky 1992: 167).

Laskowski (2003: 606-608) zmodyfikował koncepcję Kühna i zaproponował model bardziej dostosowany do realiów nauczania języków obcych poza krajami, w których te języki są językami ojczystymi, ponieważ sytuacja wyjściowa uczących się języków obcych oraz ich nauczycieli jest całkiem inna niż w krajach języków docelowych. Uwzględniając powyższe uwarunkowania, zrealizowanie pierwszego frazeodydaktycznego etapu nie jest możliwe, ponieważ związki frazeologiczne są raczej nieznane, abstrahując już od prawidłowego odczytania semantyczno-pragmatycznego. Laskowski przyłącza się do uwag Einecke (1991: 31ff), który twierdzi, iż w praktycznym nauczaniu i uczeniu się związków frazeologicznych należy uwzględnić następujące aspekty: indukcyjny sposób wprowadzenia, połączenie językowych schematyzmów z innymi zakresami językowymi, uchwycenie jednostek frazeologicznych i przysłów w kontekście, permanentne uchwycenie, tematyzacja i pogłębienie materiału już opanowanego, uzupełnienie materiału opanowanego w języku mówionym. Ponieważ frazeologizmy charakteryzują szczególnie wymiar kulturowo-społeczny, wyznaczają one zadania glottodydaktyki, które wpływają na błędy i nieporozumienia językowe w trakcie translacji. Model Laskowskiego składa się z 4 etapów. Pierwsza faza, zwana fazą receptywno-pasywną, wykorzystuje pisane i mówione autentyczne teksty obcojęzyczne. W jej skład wchodzą reprezentacja kontekstowa, eksplikacja semantyczno-syntaktyczna (słownik i/lub nauczyciel), użycie sytuacyjne (krótkie zdania, proste sytuacje), podkreślenie i uwydatnienie aspektów interlingwalnych i interkulturowych, możliwe własne tworzenie krótkich kontekstów w zależności od wieku i kompetencji językowej uczniów. Druga faza, która służy utrwaleniu wiadomości, zwana jest fazą aktywnoreceptywną i pasywno-produktywną i obejmuje (pisane lub mówione autentyczne teksty obcojęzyczne) kontekstowe rozpoznanie wcześniej poznanych frazeologizmów, uwrażliwienie strukturalno-semantyczne w obrębie znanych frazeologizmów, możliwą własną produkcję krótkich tekstów w zależności od wieku i kompetencji językowej uczniów. Kolejny etap poświęcony jest komu- 
nikacji i jest etapem produktywnym, w którym tworzone są własne teksty pisane i mówione. Wiadomości te wspierane są przez kontekstualizację z wartością semantyczną, postacią strukturalną, zastosowaniem adekwatnym do sytuacji i adresata. Ostatnią fazą omawianego modelu jest część powtórzeniowa, skierowana na zapewnienie i przekonanie ucznia o oporności i frazeologicznej indywidualności użycia języka. Jest to faza receptywno-produktywna, w której wykorzystuje się teksty obcojęzyczne oraz w języku ojczystym $\mathrm{z}$ ćwiczeniami wpływającymi motywująco na dalsze autonomiczne uczenie się frazeologii. Szczególnie ważne jest odważne i pewne przetransponowanie składników kognitywnych, semantycznych i syntaktycznych na poziom realizacji językowej, poprawne przejście do sytuacji komunikatywnych z wewnętrznym przekonaniem o poprawności językowej, wsparcie zdobytych wiadomości za pomocą różnych technik: performancji z wyobrażeniem, parafrazy, wyjaśnienia etymologicznego, przyporządkowania tematycznego, malowania, rysowania obrazów językowych, pantomimy, płaszczyzny konfrontatywnej, pragmatycznej i stylistycznej. Należy tu zastosować zestaw ćwiczeń z zakresu frazeologii w wybranych blokach tematycznych.

Ostatecznym wynikiem badań są materiały frazeodydaktyczne wygenerowane na podstawie powyższej analizy biblizmów w świetle frazeodydaktyki, które przedstawiamy tutaj $\mathrm{w}$ formie bardzo ograniczonej. Zgodnie $\mathrm{z}$ gradacją trudności najpierw winny być wprowadzane frazeologizmy lub pojedyncze leksemy o pełnej ekwiwalencji, zwłaszcza na poziomie mniej zaawansowanym. Poniżej zamieszczono fragment takiego przykładowego zadania zamkniętego:

Polecenie: Połacz przedstawione poniżej osoby z wypowiedziami charakterystycznymi dla tych osób (lub o tych osobach): Eg.1. Judas, 2. Pharisee

A. If you pay more I'm ready to repeat this accusation in front of a TV camera.

B. I have to tell the boss that Megan's come to work 10 minutes later for the second time this month.

W tej kategorii mogą także znaleźć się klasyczne ćwiczenia polegające na dopasowaniu definicji do danego leksemu/frazeologizmu. Wersja otwarta takiego ćwiczenia zakłada polecenie utworzenia krótkich dialogów z wykorzystaniem frazeologizmu/leksemu.

Przyswajanie trudniejszych związków frazeologicznych, tzn. reprezentujących ekwiwalencję częściową lub zerową, może odbywać się poprzez poniższe ćwiczenie, odzwierciedlające specyfikę nauczania na poziomie powyżej średnio zaawansowanego w seminariach. To zadanie nie tylko przygotowuje do wygłaszania homilii, ale i wyczula na zjawisko homonimii frazeologicznej:

Polecenie: Wybierz kilkuwersowy wyjątek z Biblii i następnie przygotuj wypowiedź (7-10-minutowa) oparta na wybranym fragmencie. W wypowiedzi wyko- 
rzystaj 5-10 zwrotów pochodzacych z Biblii o znaczeniu przenośnym (np. Sodoma i Gomora, nie jako miasta biblijne, ale jako 'niemoralne postępowanie').

Ilustracje, a nawet mimika, ułatwiają studentom proces zgłębienia kognitywnych motywacji biblizmów, a zatem winna być ułatwiona asymilacja form strukturalnych.

$\mathrm{Np}$

a) forehead

to toil by the sweat of one's

b) face

c) brow

Powyższy punkt z testu wyboru można opatrzyć ilustracjami części ciała lub gestami imitującymi wycieranie potu, odpowiednio z czoła, twarzy lub brwi. Biblizmy mogą też stanowić leksykon do wykorzystania w procesie przyswajania zagadnień gramatycznych, a także do wprowadzania grup leksykalnych (np. biblizmy somatyczne).

\section{Literatura}

Bąba, S., Dziamska, G., Liberek J. 2002, Słownik frazeologiczny współczesnej polszczyzny, Warszawa.

Burger, H. 1998, Phraseologie. Eine Einführung am Beispiel des Deutschen, Berlin.

Czekierda, K. 2004, Stownik terminów i zwrotów religijnych, Kraków.

Einecke, G. 1991, Unterrichtsideen Integrierter Grammatikunterricht. Textproduktion und Grammatik, Stuttgart.

Ettinger, S. 1998, Einige Überlegungen zur Phraseodidaktik, [w:] Europäische Phraseologie im Vergleich: Gemeinsames Erbe und kulturelle Vielfalt, red. W. Eismann, Bochum, s. 201-217.

Fisiak, J. 1996, Słownik idiomów angielskich, Warszawa.

Godyń, J. 1995, Maly stownik biblizmów języka polskiego, Kraków-Warszawa.

Hessky, R. 1992, Aspekte der Verwendung von Phraseologismen im Unterricht Deutsch als Fremdsprache, [w:] Fremdsprache lehren und lernen 21, s. $159-168$.

Kłosińska, A., Sobol E., Stankiewicz A. 2005, Wielki słownik frazeologiczny $P W N$ z przystowiami, Warszawa.

Kühn, P. 1994, Pragmatische Phraseologie: Konsequenzen für die Phraseographie und Phraseodidaktik, [w:] Europhras 92. Tendenzen der Phraseologieforschung, red. B. Sandig, Bochum, s. 411-428.

Laskowski, M. 2003, Semantische und pragmatische Aspekte der deutschen und polnischen Phraseologie, Zielona Góra. 
Laskowski, M. 2004, Toponyme im Bereich der phraseologischen Subsysteme des Deutschen und des Polnischen: ein Beitrag zu ihrer konfrontativen Untersuchung und didaktischen Potenz, Info Daf-Informationen Deutsch als Fremdsprache, nr 6, s. 566-616.

Müldner-Nieckowski, P. 2004, Wielki stownik frazeologiczny języka polskiego, Warszawa.

Müldner-Nieckowski, P., Müldner-Nieckowski Ł. 2004, Nowy szkolny stownik frazeologiczny, Warszawa.

Podracki, J. 1998, Szkolny stownik nauki o języku, Warszawa.

Polański, K. 1999, Encyklopedia językoznawstwa ogólnego, Wrocław-Warszawa-Kraków.

Seidl, J., McMordie W. 1988, English Idioms, Oxford.

Stownik języka polskiego PWN 2004, CD wersja 1.0, Wydawnictwo Naukowe PWN S.A.

Wolfram-Romanowska, D., Kaszubski, P., Parker, M. 2002, Idiomy polsko-angielskie, Warszawa.

\section{The translation analysis of selected biblisms and their didactic implementation in missionary seminaries}

\section{Summary}

The authors scrutinize the notion of biblisms from the point of view of didactics and translation. Biblisms, phraseological units derived from or motivated by the Bible translations, pose a considerable difficulty in the translation process, especially for missionaries and seminary students. To begin with, the authors put forward their own extensive typology of biblisms. Equivalence, a crucial factor behind the translation process, is then analyzed along with typical sources of errors in the translation process. The analysis of the author's research, the theory of translation and phraseodidactics foundations resulted in generation of teaching techniques and specific teaching materials to be implemented in the seminary classes.

Keywords: translation, specialized language, phraseology, biblism, phraseodidactics, language of missionaries, 